\title{
Pengaruh Pemberian Minuman Karbohidrat (Maltodekstrin 12,5\%) Praoperasi terhadap Kejadian Mual dan Muntah Pascamastektomi
}

\author{
Andre Aditya, ${ }^{1,2}$ Iwan Fuadi, ${ }^{3}$ Iwan Abdul Rachman ${ }^{3}$ \\ ${ }^{1}$ Lembaga Pengelola Dana Pendidikan Republik Indonesia, ${ }^{2}$ Rumah Sakit Umum Daerah Banten, \\ ${ }^{3}$ Departemen Anestesiologi dan Terapi Intensif \\ Fakultas Kedokteran Universitas Padjadjaran/RSUP Dr. Hasan Sadikin Bandung
}

\begin{abstract}
Abstrak
Mual dan muntah pascaoperasi (postoperative nausea and vomiting, PONV) menjadi masalah yang umum terjadi setelah operasi mastektomi dengan angka kejadian berkisar 21-92\%. Pemberian minuman karbohidrat (CHO) praoperasi ditawarkan sebagai sebuah solusi menurunkan PONV dan juga merupakan salah satu komponen penting dan disarankan untuk mencapai enhanced recovery after surgery (ERAS). CHO berhubungan dengan penurunan katabolisme dan resistensi insulin pascaoperasi. Penelitian ini bertujuan mengetahui pengaruh pemberian minuman berkarbohidrat ( $\mathrm{CHO}$ ) oral sebelum operasi terhadap tingkat kejadian PONV pascaoperasi mastektomi. Penelitian menggunakan eksperimental uji acak buta tunggal di Rumah Sakit Dr. Hasan Sadikin (RSHS) Bandung pada November 2019-Februari 2020. Sebanyak 46 pasien dibagi menjadi dua kelompok, yakni kelompok K (kelompok kontrol, air mineral, $\mathrm{n}=23$ subjek) dan kelompok C (kelompok CHO, $\mathrm{n}=23$ subjek). Analisis data hasil penelitian dilakukan dengan Uji Mann-hitney. Kejadian mual muntah pada kelompok kontrol lebih besar dibanding dengan kelompok CHO pada menit 0-30 (57\% vs $22 \%$ ), pada menit $30-60$ (91\% vs 61\%), dan pada menit $60-120$ (78\% vs $61 \%$ ) dengan perbedaan yang bermakna $(\mathrm{p}<0,05)$. Simpulan, pemberian minuman karbohidrat praoperasi dapat menurunkan kejadian mual muntah pascamastektomi dibandingkan dengan kelompok kontrol.
\end{abstract}

Kata kunci: Mastektomi, maltodekstrin 12,5\%, CHO, post operative nausea vomiting, enhanced recovery after surgery

\section{Effect of Preoperative Oral Carbohydrate Supplementation (Maltodextrin 12.5\%) on Post-Mastectomy Nausea and Vomiting Incidence}

\begin{abstract}
Postoperative nausea and vomiting (PONV) is a common problem after surgery. Mastectomy is one of surgeries with a high-risk for PONV, which is seen in $21-92 \%$ of the patients. Preoperative carbohydrate (CHO) drinks are offered to reduce PONV. The provision of CHO is also important as it is recommended to obtain enhanced recovery after surgery (ERAS). CHO is associated with reduced catabolism and postoperative insulin resistance. This study aimed to determine the effect of oral carbohydrate (CHO) drinks before surgery on the incidence of postoperative PONV in mastectomy. This was an experimental singleblind randomized study conducted in Dr. Hasan Sadikin General Hospital (RSHS) Bandung, Indonesia. A total of 46 patients were divided into two groups, namely group $\mathrm{K}$ (control group, mineral water, $\mathrm{n}=23$ subjects) and group $\mathrm{C}$ ( $\mathrm{CHO}$ group, $\mathrm{n}=23$ subjects). Data collected were then analyzed using the Mann Whitney test and the results showed that during PONV incidence rates were significantly higher 0-30 minutes after the surgery ( $57 \%$ vs $22 \%$ ), $30-60$ minutes after the surgery ( $91 \%$ vs $61 \%$ ), and $60-120$ minutes ( $78 \%$ vs $61 \%$ ) $(\mathrm{p}<0.05)$. Therefore, the administration of preoperative carbohydrate drinks can reduce the incidence of postoperative nausea and vomiting in mastectomy
\end{abstract}

Key words: Mastectomy, maltodextrin $12.5 \%$, CHO, post-operative nausea and vomiting, enhanced recovery after surgery

Korespondensi: Andre Aditya, dr, Rumah Sakit Umum Daerah Banten, Jalan Syeh Nawawi Al Bantani, Kelurahan Banjarsari, Kecamatan Cipocok Jaya, Banjarsari, Serang, Banjarsari, Kec. Cipocok Jaya, Kota Serang, Banten 42123, Tlpn (0254) 8490911 Email: dashcreworud@gmail.com 


\section{Pendahuluan}

Kejadian mual dan muntah pascaoperasi (postoperative nausea and vomiting; PONV) menjadi masalah yang umum terjadi setelah operasi. Kejadian mual dan muntah pascaoperasi didefinisikan sebagai episode mual dan muntah dalam periode 24 jam setelah operasi. ${ }^{1}$ Kejadian mual dan muntah pascaoperasi pada populasi umum berkisar $20-30 \%$ dan $70-80 \%$ pada pasien berisiko tinggi. ${ }^{1,2}$ Angka kejadian ini tetap tinggi walaupun prosedur anestesi modern dan obat antiemetik yang lebih baik sudah diterapkan. ${ }^{3}$

Kejadian mual dan muntah pascaoperasi menyebabkan durasi rawat inap memanjang sehingga berdampak pada kerugian ekonomi. ${ }^{1,4}$ Mual dan muntah juga dapat menyebabkan morbiditas seperti aspirasi, ruptur esofagus (pada pasien varises esofagus), hematoma pada luka operasi, dehidrasi, ketidakseimbangan elektrolit, dan gangguan pada lokasi insisi. ${ }^{1,5}$

Mastektomi merupakan salah satu operasi berisiko tinggi mengalami PONV dengan angka berkisar 21-92\%. Berdasar atas skor risiko PONV, mastektomi pada wanita setidaknya meningkatkan risiko PONV sebesar 3640\%. ${ }^{5,6}$ Faktor hormonal juga berperan dalam meningkatkan risiko PONV pada mastektomi terkait reseptor estrogen dan progesteron pada jaringan mammae. ${ }^{7}$

Beberapa penelitian terdahulu untuk meminimalisir risiko PONV sudah banyak dilakukan, seperti penggunaan antiemetik profilaktik, suplementasi oksigen, pemberian kanabinoid, akupunktur, dan obat-obatan herbal, namun hal-hal ini tidak sepenuhnya menurunkan risiko PONV. ${ }^{1}$ Pemberian obatobatan antiemetik dapat menyebabkan beberapa efek samping, di antaranya pusing, nyeri kepala, konstipasi, sedasi, lemah, gelisah, efek ekstrapiramidal, dan pemanjangan interval QT. ${ }^{3}$

Pemberian karbohidrat pada praoperasi ditawarkan sebagai sebuah solusi menurunkan PONV. Pemberian minuman kaya karbohidrat (CHO, rumus bangun ikatan kimia karbohidrat) praoperasi berhubungan dengan rasa lapar berkurang, kecemasan, dan rasa tidak nyaman.
Pemberian $\mathrm{CHO}$ juga berhubungan dengan penurunan katabolisme dan resistensi insulin pascaoperasi. Minuman kaya karbohidrat harganya murah, mudah didapatkan, tidak ada efek samping, dan aman. ${ }^{1}$

Pemberian $\mathrm{CHO}$ ini juga merupakan salah satu komponen penting dan disarankan untuk mencapai enhanced recovery after surgery (ERAS). Pemberian cairan sebelum operasi dapat menurunkan kejadian PONV yang berkaitan dengan puasa praoperasiyang terlalu lama. ${ }^{8}$ Kombinasi puasa berkepanjangan ditambah kehilangan cairan selama operasi menyebabkan hipovolemia dan pengurangan aliran darah ke saluran pencernaan. Jika iskemia ini tidak dikoreksi akan menyebabkan pelepasan serotonin berlebihan yang dapat mencetuskan PONV. ${ }^{9,10}$

Beberapa penelitian sudah dilaksanakan sebelumnya, penelitian yang dilakukan di India pada pasien yang menjalani prosedur laparoskopi menyatakan penurunan kejadian PONV yang signifikan pada pasien yang diberikan terapi $\mathrm{CHO}$ praoperasi dibanding dengan pasien yang tidak diberikan $\mathrm{CHO}$ sebesar $38-60 \%{ }^{1}$

Tujuan penelitian ini adalah mengetahui pengaruh pemberian minuman karbohidrat praoperasi terhadap kejadian mual dan muntah pascamastektomi.

\section{Subjek dan Metode}

Penelitian menggunakan desain uji klinis acak buta tunggal (single blind randomized controlled trial). Subjek penelitian ini adalah wanita yang menjalani mastektomi dengan kriteria inklusi berupa status fisik American Society of Anesthesiologists (ASA) I-II, usia 18-60 tahun, gula darah sewaktu $\leq 200 \mathrm{mg}$ / dL dan skor Apfel penilaian mual dan muntah kategori sedang. Kriteria eksklusi adalah pasien dengan riwayat diabetes melitus, gangguan fungsi ginjal dan hepar, gangguan irama jantung, gangguan neurologis, miopati, koagulopati, hamil, intoleransi laktosa, tidak memahami angka, dan tidak menandatangani persetujuan penelitian (informed consent).

Kriteria pengeluaran adalah pasien 
yang mengalami syok yang menetap akibat perdarahan intraoperatif (pascaoperasi menggunakan obat-obatan inotropik), durasi puasa lebih dari 4 jam, pasien mengonsumsi obat antiemetik dalam kurun waktu 24 jam sebelum operasi, dan gula darah sewaktu $\geq 200 \mathrm{mg} / \mathrm{dL}$ pada saat sebelum induksi.

Penentuan besar sampel dilaksanakan berdasar atas perhitungan perbedaan 2 (dua) rerata dengan taraf kepercayaan 95\%, kuasa uji (power test) 80\%, dan didapatkan jumlah sampel minimal untuk tiap kelompok adalah 21 orang. Pengambilan sampel dilakukan secara consecutive sampling dan alokasi subjek ke dalam salah satu kelompok dilakukan secara random blok permutasi.

Penelitian dilakukan di RSUP Dr. Hasan Sadikin Bandung, pada bulan November 2019-Februari 2020 setelah mendapatkan persetujuan dari Komite Etik Penelitian Kesehatan Rumah Sakit Dr. Hasan Sadikin Bandung No: LB.02.01/X.6.5/279/2019 Peserta penelitian yang memenuhi kriteria inklusi dan tidak termasuk kriteria eksklusi diberikan penjelasan mengenai prosedur penelitian serta menandatangani persetujuan pada saat praoperasi (informed consent). Pasien diajarkan untuk menilai intensitas mual mereka menggunakan NRS (skor 0 sampai dengan 10). Subjek penelitian dibagi menjadi 2 kelompok, kelompok kontrol (K) diberikan air mineral $400 \mathrm{~mL}$ pada $2-4$ jam praoperasi; kelompok maltodekstrin (C) diberikan maltodekstrin 50 g yang dilarutkan dalam air mineral sampai $400 \mathrm{~mL}$ pada $2-4$ jam praoperasi. Pasien dipuasakan 6 jam untuk makanan padat.

Pasien dilakukan pengecekan gula darah sewaktu sebelum induksi. Pasien dilakukan tindakan mastektomi dengan anestesi umum, diberikan fentanil $2 \mu \mathrm{g} / \mathrm{kgBB}$, propofol $2-3 \mathrm{mg} /$ $\mathrm{kgBB}$, atrakurium $0,5 \mathrm{mg} / \mathrm{kgBB}$, lalu dilakukan intubasi endotrakeal. Rumatan anestesi dengan sevofluran, $\mathrm{O}_{2}$ dan $\mathrm{N}_{2} \mathrm{O} \quad 50 \%: 50 \%$, pasien diberikan profilaksis deksametason $5 \mathrm{mg}$ sebagai profilaksis muntah. Subjek penelitian dinilai kejadian mual dan muntah pada menit ke-30, 60, 120 menit, 6 jam, 12 jam, dan 24 jam pascaoperasi. Jika masih muntah diberikan propofol $10 \mathrm{mg}$ intravena. Untuk analgetik pascaoperasi digunakan petidin 1 $\mathrm{mg} / \mathrm{kgBB} / 6$ jam dan ketorolak 0,5 mg/kgBB. Pasien diberikan makan dan minum segera setelah pasien sadar penuh pascaoperasi.

Analisis statistik untuk data deskriptif ditampilkan merupakan bentuk distribusi frekuensi dan persentase. Analisis data numerik dilakukan dengan Uji normalitas Shapiro-Wilk dan dianalis menggunakan uji-t tidak berpasangan dan Uji Mann-Whitney sesuai distribusi data. Analisis data ordinal dilakukan Uji Mann-Whitney dan analisis dari data kategorik menggunakan uji chi-square. Pengolahan data menggunakan software $\mathrm{R}$.

\section{Hasil}

Hasil analisis statistika menunjukkan bahwa karakteristik subjek penelitian menurut usia, berat badan, tinggi badan, tipe operasi, riwayat merokok, riwayat PONV, status fisik ASA, lama anestesi dan riwayat kemoterapi, penilaian NRS nyeri, jumlah opioid diberikan, penggunaan agen reverese neostigmin, jumlah cairan, serta perdarahan durante operasi dan hemodinamik pascaoperasi antara kedua kelompok tidak berbeda bermakna ( $\mathrm{p}>0,05$; Tabel 1). Apabila syarat dari chi-square tidak terpenuhi, nilai kemaknaan berdasar atas nilai $\mathrm{p}<0,05$. Tanda* menunjukkan nilai $\mathrm{p}<0,05$ artinya signifkan atau bermakna secara statistik. $\mathrm{RM}=$ radical mastectomy, $\mathrm{MRM}=$ modified radical mastectomy, $\mathrm{SM}=$ simple mastectomy.

Kejadian PONV pada kelompok minuman berkarbohidrat ( $\mathrm{CHO}$ ) lebih kecil dibanding dengan kelompok kontrol pada menit ke0-120 dengan perbedaan yang signifikan $(\mathrm{p}<0,05)$, namun tidak didapatkan perbedaan siginifikan setelah menit 120 hingga 24 jam pascaoperasi ( $p>0,05$; Tabel 2).

\section{Pembahasan}

Analisis kriteria umum serta faktor risiko mual dan muntah pascaoperasi pada subjek penelitian ini berdasar atas usia, berat badan, tinggi badan, tipe operasi, riwayat merokok, 
Tabel 1 Perbandingan Karakteristik Subjek Penelitian antara Kedua Kelompok

\begin{tabular}{|c|c|c|c|}
\hline \multirow{3}{*}{ Variabel } & \multicolumn{2}{|c|}{ Kelompok } & \multirow{3}{*}{ Nilai p } \\
\hline & Kontrol (K) & CHO (C) & \\
\hline & $n=23$ & $n=23$ & \\
\hline Usia (tahun) & & & 0,279 \\
\hline Mean \pm Std & $46,78 \pm 9,74$ & $49,52 \pm 6,97$ & \\
\hline Median & 47 & 49 & \\
\hline Range (min.-maks.) & $27,00-63,00$ & $35,00-64,00$ & \\
\hline Berat badan (kg) & & & 0,207 \\
\hline Mean \pm Std & $59,96 \pm 6,73$ & $57,57 \pm 5,91$ & \\
\hline Median & 60,00 & 58,00 & \\
\hline Range (min.-maks.) & $48,00-72,00$ & $45,00-68,00$ & \\
\hline Tinggi badan $(\mathrm{cm})$ & & & 0,383 \\
\hline Mean \pm Std & $152,70 \pm 5,91$ & $154,3 \pm 6,13$ & \\
\hline Median & 152,00 & 156,00 & \\
\hline Range (min.-maks.) & $143,00-167,00$ & $142,00-164,00$ & \\
\hline Tipe operasi, n (\%) & & & 0,408 \\
\hline SM & 21 & 19 & \\
\hline MRM & 1 & 3 & \\
\hline $\mathrm{RM}$ & 1 & 1 & \\
\hline Riwayat merokok, n & 1 & 1 & 1,000 \\
\hline Riwayat PONV, n & 1 & 2 & 1,000 \\
\hline ASA, n & & & 1,000 \\
\hline ASA 1 & 1 & 2 & \\
\hline ASA 2 & 22 & 21 & \\
\hline Lama anestesi (menit) & & & 0,841 \\
\hline $0-120$ & 3 & 2 & \\
\hline$>180$ & 7 & 7 & \\
\hline Riwayat kemoterapi, $\mathrm{n}$ & 21 & 22 & 1,000 \\
\hline NRS nyeri, $\mathrm{n}$ & & & 1,000 \\
\hline Nyeri Ringan & 23 & 23 & \\
\hline Nyeri Sedang & 0 & 0 & \\
\hline Nyeri Berat & 0 & 0 & \\
\hline Jumlah fentanyl durante operasi ( $\mu \mathrm{g})$ & & & 0,533 \\
\hline Mean \pm Std & $151,10 \pm 14,05$ & $155,40 \pm 19,88$ & \\
\hline Median & 150,00 & 150,00 & \\
\hline Range & $125,00-175,00$ & $125,00-200,00$ & \\
\hline Jumlah petidin pascaoperasi (mg) & & & 0,6987 \\
\hline Mean \pm Std & $145,70 \pm 33,41$ & $134,80 \pm 55,25$ & \\
\hline Median & 150,00 & 150,00 & \\
\hline Range & $0,00-200,00$ & $0,00-200,00$ & \\
\hline
\end{tabular}




\begin{tabular}{|c|c|c|c|}
\hline \multirow{3}{*}{ Variabel } & \multicolumn{2}{|c|}{ Kelompok } & \multirow{3}{*}{ Nilai p } \\
\hline & Kontrol (K) & CHO (C) & \\
\hline & $\mathbf{n}=\mathbf{2 3}$ & $n=23$ & \\
\hline Jumlah neostigmin (mg) & & & 0,5548 \\
\hline Mean \pm Std & $0,49 \pm 0,05$ & $0,478 \pm 0,07$ & \\
\hline Median & 0,50 & 0,50 & \\
\hline Range & $0,25-0,50$ & $0,25-0,50$ & \\
\hline Kejadian hipotensi, $\mathrm{n}$ & 0 & 0 & 1,000 \\
\hline Perdarahan durante operasi (mL) & & & 0,7238 \\
\hline Mean \pm Std & $412,60 \pm 171,55$ & $380,70 \pm 141,27$ & \\
\hline Median & 370.00 & 350.00 & \\
\hline Range & $180,00-1.000,00$ & $100,00-800.00$ & \\
\hline Jumlah cairan durante operasi (mL) & & & 0,7461 \\
\hline Mean \pm Std & $1,470.00 \pm 440,49$ & $1,430.00 \pm 515,61$ & \\
\hline Median & $1,500.00$ & $1,500.00$ & \\
\hline Range & $700.00-2,500.00$ & $500.00-3,300.00$ & \\
\hline
\end{tabular}

Keterangan: untuk data numerik nilai p diuji dengan ujit tidak berpasangan apabila data berdistribusi normal dengan alternatif Uji Mann Whitney apabila data tidak berdistribusi normal. Data kategorik nilai p dihitung berdasar atas uji chi-square dengan alternatif Uji Kolmogorov Smirnov dan Exact Fisher

riwayat PONV, status fisik ASA, lama anestesi dan riwayat kemoterapi, penilaian NRS nyeri pascaoperasi, jumlah opioid (fentanil dan petidin), penggunaan agen reverese neostigmin, jumlah cairan durante operasi, perdarahan durante operasi dan hemodinamik pascaoperasi tidak berbeda bermakna antara kedua kelompok $(p>0,05)$ sehingga dapat disimpulkan bahwa kedua kelompok penelitian homogen dan layak dibandingkan.

Pada penelitian ini didapatkan kejadian mual muntah pada kelompok $\mathrm{CHO}$ lebih rendah dibanding dengan kelompok kontrol pada waktu 0-120 menit dengan perbedaan yang signifikan $(p<0,05)$. Kejadian mual muntah paling tinggi terjadi pada menit 30-60 dengan peningkatan mual muntah pada kedua kelompok.

Patofisiologi mual muntah pascaoperasi disebabkan oleh berbagai macam faktor seperti stres pembedahan yang menyebabkan pelepasan hormon counter regulatory sehingga terjadi peningkatan katekolamin, pelepasan hormon kortisol, glukagon dan growth hormon yang menyebabkan peningkatan serotonin.
Proses tersebut menyebabkan pengambilan glukosa pada jaringan perifer sebagai sumber energi selama operasi. Pelepasan serotonin ini ditangkap oleh chemoreceptor trigger zone (CTZ) sebagai substansi emetik yang menyebabkan PONV. Pada pemberian CHO praoperasi didapatkan kadar glukosa dalam sirkulasi terjaga sehingga pengambilan glukosa dari jaringan perifer akibat pelepasan hormon counter regulatory berkurang karena masih didapatkan glukosa dalam sirkulasi dan secara tidak langsung menurunkan pelepasan serotonin sehingga PONV berkurang.8, ${ }^{8,11,12}$

Pada pasien yang menjalani operasi dilakukan puasa praoperasiyang menyebabkan tidak ada asupan glukosa selama masa puasa. Penurunan asupan glukosa menyebabkan glukosa di dalam sirkulasi akan berkurang sehingga terjadi proses katabolisme selama pembedahan menggunakan glukosa pada jaringan perifer sebagai sumber energi yang menyebabkan resistensi insulin. Pemberian CHO praoperasi dapat menurunkan resistensi insulin dikarenakan masih terdapat glukosa di dalam sirkulasi selama masa operasi sehingga 
Tabel 2 Proporsi Kejadian Mual Muntah berdasarkan atas Waktu Perlakuan antara Kelompok Kontrol dan CHO

\begin{tabular}{|c|c|c|c|}
\hline \multirow{3}{*}{ Variabel } & \multicolumn{2}{|c|}{ Kelompok } & \multirow{3}{*}{ Nilai p } \\
\hline & $\mathbf{P}$ & $\mathbf{0}$ & \\
\hline & $n=23$ & $n=23$ & \\
\hline $0-30$ menit & & & $0,0048^{*}$ \\
\hline Tidak mual & 10 & 18 & \\
\hline Ponv ringan & 5 & 4 & \\
\hline Ponv sedang & 5 & 0 & \\
\hline Ponv berat & 3 & 1 & \\
\hline 30-60 menit & & & $0,0042^{*}$ \\
\hline Tidak mual & 2 & 9 & \\
\hline Ponv ringan & 10 & 9 & \\
\hline Ponv sedang & 3 & 3 & \\
\hline Ponv berat & 8 & 2 & \\
\hline $60-120$ menit & & & $0,048^{*}$ \\
\hline Tidak mual & 5 & 9 & \\
\hline Ponv ringan & 12 & 13 & \\
\hline Ponv sedang & 4 & 1 & \\
\hline Ponv berat & 2 & 0 & \\
\hline $2-6 \mathrm{jam}$ & & & 0,1007 \\
\hline Tidak mual & 12 & 16 & \\
\hline Ponv ringan & 10 & 7 & \\
\hline Ponv sedang & 1 & 0 & \\
\hline Ponv berat & 0 & 0 & \\
\hline 6-12 jam & & & 0,173 \\
\hline Tidak mual & 19 & 22 & \\
\hline Ponv ringan & 4 & 1 & \\
\hline Ponv sedang & 0 & 0 & \\
\hline Ponv berat & 0 & 0 & \\
\hline 12-24 jam & & & 0,349 \\
\hline Tidak mual & 18 & 20 & \\
\hline Ponv ringan & 5 & 3 & \\
\hline Ponv sedang & 0 & 0 & \\
\hline Ponv berat & 0 & 0 & \\
\hline
\end{tabular}

Keterangan: untuk data ordinal nilai p diuji dengan uji Mann Whitney. Nilai kemaknaan berdasar atas nilai $\mathrm{p}<0,05$. Tanda* menunjukkan nilai $\mathrm{p}<0,05$ artinya signifikan atau bermakna secara statistik

sensitivitas insulin terjaga. Resistensi insulin ini diperberat dengan kekurangan cairan. Kehilangan cairan intraoperatif ditambah dengan puasa berkepanjangan menyebabkan iskemia gastrointestinal dan memicu pelepasan serotonin yang ditangkap oleh CTZ via reseptor 5-HT3. Rangsangan iskemia GIT menstimulasi rangsang vagal dari pusat 
emetik sehingga terjadi PONV. ${ }^{1,9,10,13}$

Pada penelitian ini didapatkan efek $\mathrm{CHO}$ dalam menurunkan kejadian PONV signifikan dalam 0-120 menit dan tidak signifikan pada 2-24 jam pascaoperasi. Hal ini tidak sesuai dengan penelitian sebelumnya yang dilakukan pada 40 pasien yang menjalani operasi laparoskopik kolesistektomi yang menunjukkan pemberian $\mathrm{CHO}$ mengurangi PONV hingga 24 jam pascaoperasi. ${ }^{14}$ Perbedaan hasil penelitian ini dengan sebelumnya dapat disebabkan oleh pemberian deksametason sebagai untuk profilaksis PONV yang pada penelitian ini menurunkan angka kejadian late PONV (PONV yang terjadi lebih dari 6 jam pascaoperasi).

Penelitian pada tahun 2014 menunjukkan bahwa pasien yang diberikan deksametason preinduksi didapatkan angka kejadian early PONV (PONV dalam 6 jam pertama pascaoperasi) sebanyak $40 \%$ dan tidak ada kejadian PONV pada 6-24 jam pascaoperasi. Penelitian lain tahun 2011 yang meneliti tentang penggunaan steroid dalam menurunkan insidens PONV didapatkan bahwa steroid efektif dalam mencegah late PONV dan kurang efektif pada early PONV. ${ }^{15,16}$ Dalam penelitian ini deksametason diduga menghambat PONV pada 2-24 jam pascaoperasi sehingga didapatkan hasil bahwa kelompok kontrol dan CHO tidak berbeda signifikan dalam menurunkan PONV 2-24 jam pascaoperasi. Dalam hal ini CHO dapat berfungsi sebagai terapi tambahan pencegahan PONV.

Salah satu komplikasi yang ditakutkan dengan pemberian minuman karbohidrat adalah aspirasi. Pada penelitian ini tidak didapatkan kejadian aspirasi dan regurgitasi, hal ini dikuatkan oleh penelitian di India yang juga menyatakan bahwa komplikasi anestesi seperti aspirasi tidak terjadi pada kelompok yang diberikan minuman sebanyak $400 \mathrm{~mL}$ 2-4 jam praoperasi. Penelitian yang dilakukan di Turki tahun 2013 menyatakan bahwa pemberian minuman karbohidrat dua jam praoperasi menurunkan mual muntah dan tidak berpengaruh terhadap gastric residual volume antara kelompok $\mathrm{CHO}$ dan kelompok puasa praoperasi, hal ini membuktikan pemberian CHO 2-4 jam praoperasi aman digunakan. ${ }^{1,14}$

Kekurangan pada penelitian ini adalah tidak dilakukan pemeriksaan gula darah durante operasi dan pascaoperasi sebagai prediktor awal resistensi insulin akibat stres pembedahan. Resistensi insulin merupakan salah satu faktor penyebab PONV akibat produksi hormon counter regulatory yang meningkatan kadar gula darah selama operasi sehingga diperlukan pemeriksaan kadar gula darah durante operasi dan pascaoperasi. ${ }^{11,12}$

\section{Simpulan}

Berdasar atas hasil penelitian dan pembahasan di atas maka dapat ditarik simpulan bahwa pemberian minuman karbohidrat praoperasi dapat menurunkan kejadian mual muntah pascamastektomi.

\section{Daftar Pustaka}

1. Singh BN, Dahiya D, Bagaria D, Saini V, Kaman L, Kaje V, dkk. Effects of preoperative carbohydrates drinks on immediate postoperative outcome after day care laparoscopic cholecystectomy. Surg Endosc. 2015;29(11):3267-72.

2. de Souza DS, Costa AF, Chaves GV. Predisposing factors for postoperative nausea and vomiting in gynecologic tumor patients. Support Care Cancer. 2016;24(11):4661-7.

3. Mishra A, Pandey RK, Sharma A, Darlong V, Punj J, Goswami D, dkk. Is perioperative administration of $5 \%$ dextrose effective in reducing the incidence of PONV in laparoscopic cholecystectomy?: a randomized control trial. J Clin Anesth. 2017;40:7-10.

4. Garg S, Subramani S, Sachdeva H. Postoperative nausea and vomiting: The achilles heel of anesthesiologists. J Anaesthesiol Clin Pharmacol. 2017;33(4):427-8.

5. Geralemou S, Gan TJ. Assessing the value of risk indices of postoperative nausea and vomiting in ambulatory surgical patients. 
Curr Opin Anaesthesiol. 2016;29(6):66873.

6. Chatterjee S, Rudra A, Sengupta S. Current concepts in the management of postoperative nausea and vomiting. Anesthesiol Res Pract. 2011;2011(1): 748031.

7. Bakshi SG, Jibhkate B, Sareen R, Badwe R. Nausea and vomiting after breast cancer surgery, and relationship with tumor receptor status. J Anesth. 2012;26(2):18795.

8. Mishra R, Kapoor I, Mahajan C, Prabhakar H. Enhanced recovery after surgery: neuroanaesthetic perspective. J Neuroanaesthesiol Crit Care. 2017;4(1):17-22.

9. Ismail EA, Bakri MH, Abd-Elshafy SK. Dexamethasone alone versus in combination with intra-operative superhydration for postoperative nausea and vomiting prophylaxis in female patients undergoing laparoscopic cholecystectomy: a randomized clinical trial. Korean J Anesthesiol. 2017;70(5):535-41.

10. Yavuz MS, Kazancı D, Turan S, Aydınlı B, Selçuk G, Özgök A, dkk. Investigation of the effects of preoperative hydration on the postoperative nausea and vomiting. BioMed Res Int. 2014;2014:4.
11. J Fawcett W, Ljungqvist O. Starvation, carbohydrate loading, and outcome after major surgery. BJA Education. 2017;17(9):312-6.

12. Duggan EW, Carlson K, Umpierrez GE. Perioperative hyperglycemia management: an update. Anesthesiology. 2017;126(3):547-60.

13. Pierre $S$, Whelan R. Nausea and vomiting after surgery. Continuing Eduin Anaesth Crit Care Pain. 2013;13(1):28-32.

14. Yilmaz N, Çekmen N, Bilgin F, Erten E, Özhan MÖ, Coşar A. Preoperative carbohydrate nutrition reduces postoperative nausea and vomiting compared to preoperative fasting. J Res Medi Sci: Offic J Isfahan Univers Med Sci. 2013;18(10):827.

15. Gan TJ, Diemunsch P, Habib AS, Kovac A, Kranke P, Meyer TA, dkk. Consensus guidelines for the management of postoperative nausea and vomiting. Anesth Analg. 2014;118(1):85-113.

16. Tobi $\mathrm{K}$, Imarengiaye $\mathrm{C}$, Amadasun $\mathrm{F}$. The effects of dexamethasone and metoclopramide on early and late postoperative nausea and vomiting in women undergoing myomectomy under spinal anaesthesia. Nigerian J Clin Pract. 2014;17(4):449-55. 